\title{
Nutrient content, uptake and fertility influenced by sources and levels of sulphur in Kharif sesame (Sesamum indicum L.)
}

\author{
BHAINRU SAINI*, B.T. PATEL ${ }^{1}$ AND B.L. YADAV ${ }^{2}$ \\ Department of Agricultural Chemistry and Soil Science, C.P. College of Agriculture, Sardarkrushinagar \\ Dantiwada Agricultural University, SARDARKRUSHINAGAR (GUJARAT) INDIA
}

\begin{abstract}
An field experiment was conducted at the Agronomy Instructional Farm, Chimanbhai Patel College of Agriculture, Sardarkrushinagar Dantiwada Agricultural University, Sardarkrushinagar during Kharif 2012. Total eight treatment combinations comprised of two sources of sulphur viz., $\mathrm{S}_{1}=$ Elemental sulphur and $\mathrm{S}_{2}=$ Gypsum and four levels of sulphur viz., $\mathrm{L}_{1}=15 \mathrm{~kg} \mathrm{~S} \mathrm{ha}^{-1}, \mathrm{~L}_{2}=30 \mathrm{~kg} \mathrm{~S} \mathrm{ha}^{-1}, \mathrm{~L}_{3}=45 \mathrm{~kg} \mathrm{~S} \mathrm{ha}^{-1}$ and L $\mathrm{L}_{4}=$ $60 \mathrm{~kg} \mathrm{~S} \mathrm{ha}^{-1}$ were tried in Randomized Block Design with factorial concepts with four replications. Sesame variety GT 2 was used as a test crop. The soil of the experimental field was loamy sand in texture, alkaline in reaction and soluble salt content under safe limit. It was low in organic carbon, available $\mathrm{N}$ and $\mathrm{S}$; medium in available $\mathrm{P}_{2} \mathrm{O}_{5}, \mathrm{~K}_{2} \mathrm{O}$ and DTPA-extractable Fe and Zn and having sufficient DTPA-extractable

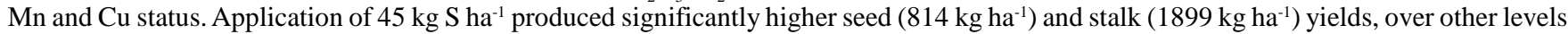
of sulphur, however, it was statistically at par with $60 \mathrm{~kg} \mathrm{~S} \mathrm{ha}^{-1}$. Significantly higher content and uptake of N, P and S by seed and stalk and available S content in soil at harvest were recorded with $45 \mathrm{~kg} \mathrm{~S} \mathrm{ha}^{-1}$, however, this treatment was statistically comparable with $60 \mathrm{~kg} \mathrm{~S}$ ha $^{-1}$.
\end{abstract}

Key Words : Sulphur, Sesame, Nutrient content, Fertility

View Point Article : Saini, Bhainru, Patel, B.T. and Yadav, B.L. (2015). Nutrient content, uptake and fertility influenced by sources and levels of sulphur in Kharif sesame (Sesamum indicum L.). Internat. J. agric. Sci., 11 (1): 146-150.

Article History : Received : 03.06.2014; Revised : 26.11.2014; Accepted : 11.12.2014

\footnotetext{
* Author for correspondence

${ }^{1}$ Micronutrient Research Scheme, Central Instrumentation Laboratory, Sardarkrushinagar Dantiwada Agricultural University, SARDARKRUSHINAGAR (GUJARAT) INDIA

${ }^{2}$ Department of Agronomy, C.P. College of Agriculture, Sardarkrushinagar Dantiwada Agricultural University, SARDARKRUSHINAGAR (GUJARAT) INDIA
} 